\title{
Workers Participation in Management with Reference to Loganathan Interior, Chennai
}

\author{
R. Ramamoorthy, P.Karthikeyan, K.Shanmughapriya
}

\begin{abstract}
The officials which understood another game plan of characteristics to work and the board. Generally the possibility of Workers' Participation in Management (WPM) implies speculation of non-managerial delegates in the fundamental administration technique of the affiliation. Workers' advantage is generally called 'work backing' or 'agent venture' in the officials. In Germany it is known as co-affirmation while in Yugoslavia it is known as self-organization. The International Labor Organization has been asking part nations to propel the arrangement of Workers' Participation in Management. [1],[ $3],[5]$
\end{abstract}

Workers' interest in the administrators recommends mental and energetic relationship of workers in the organization of Enterprise. It is considered as an instrument where workers have a state in the desicion

Keywords : Work Plan,Participation

\section{INTRODUCTION}

In workers support, there are 2 specific get-togethers of people in an undertaking viz chiefs and workers performing independently two separate game plans of limit which are known as regulatory and usable. The central refinement between the people who include authoritative positions and workers is that boss are viewed as in charge of made by their subordinates, while workers are mindful only for their work. How much workers may climb to advance toward getting to be chairmen is through a noteworthy point, yet is truly unquestionable from whether workers may take an interest in authoritative limits. [2 ],[ 4],[6]

Regulatory limits are basically stressed over masterminding , dealing with, prodding and controlling strikingly with employable limits if the region of his exercises is little . Nevertheless, in case of a noteworthy affiliation, these limits are to be performed by different game plan of people . Workers interest in the administrators attempts to interface this opening endorsing authorities to share in the authoritative method. In actuality, this is an incredibly wide viewpoint on the term workers support in the board and this

Revised Manuscript Received on July 22, 2019.

Ramamoorthy R, Department of MBA, Bharath Institute of Higher Education and Research, Tamilnadu, India. Email: ramamoorthy0071@gmail.com

P.Karthikeyan, Department of MBA, Bharath Institute of Higher Education and Research, Tamilnadu, India. Email: karthikeyan1995@gmail.com

Shanmughapriya K, Department of CSE, Bharath Institute of Highe Education and Research, Tamilnadu, India. Email: shanmugapriyabiher@gmail.com isn't essentially possible. This issue has been discussed later in this area.

\section{OBJECTIVES}

\section{A.Primary objective}

The target of the investigation is to basically assess the adequacy of laborers support in the executives

B.Secondary objective

- To discover the laborers cooperation in the board.

- To find outthat the association give proper preparing offices to workers.

- To discover that are you happy with the elements of laborers support in the board.

- To recommend appropriate measures to improve the WPM.

\section{METHODS OF DATA COLLECTION}

Information Collection is one of the significant just as characteristic advance in the examination study. Information here alludes actualities and helpful data with respect to the examination. The analyst have gathered two sorts of information from various source viz., [7],[9] ,[11]

\section{A. Primary data}

Essential information implies the crisp data (or) realities gathered from the assets. This information are utilized to break down a specific report (or) research. The essential information has been regularly all things considered by survey, Interview, etc. [8],[ 10] ,[12]

Optional information implies, the information or data are gathered by somebody, for some reason, and we can utilize it for an examination likewise, for example, Book audits, Internet sources, paper data, Research Journals and so on. Those examinations and records accessible identified with the present investigation. [13], [15] ,[ 17]

\section{B. SAMPLING METHOD \\ C. Sample population}

D. Sample Size

Sample population is 200 employees.

The sample size is taken as 120 .

The respondent of sample size is 120 which is selected on the basis of sampling method. The tools adopted to analyse the data are percentage and the research design used is descriptive research design. For the purpose of research study both primary data as well as secondary data has been collected.Simple Random Sampling method is used.

Straightforward Random Sampling. Basic arbitrary examining alludes to any inspecting technique that has the accompanying properties. The populace comprises of $\mathrm{N}$ objects. The example comprises of $n$ objects. In the event that every conceivable 
example of $\mathrm{n}$ items are similarly liable to happen, the examining strategy is called basic arbitrary inspecting. [14],[ 16], [18]

\section{RESEARCH DESIGN}

Table 1 The Company is a Leader In The Industry

\begin{tabular}{|l|l|l|}
\hline Factors & No of respondents & Percentage \\
\hline Strongly Agree & 18 & 18 \\
\hline Agree & 52 & 52 \\
\hline Neutral & 12 & 12 \\
\hline Disagree & 8 & 8 \\
\hline Strongly Disagree & 10 & 10 \\
\hline Total & 100 & 100 \\
\hline
\end{tabular}

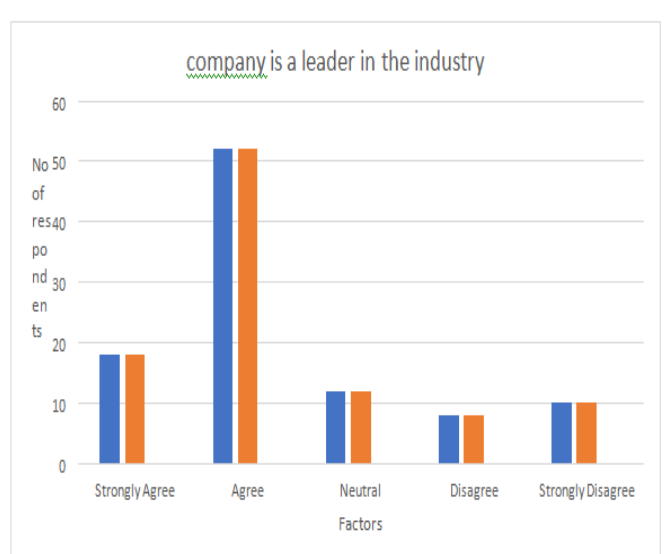

Fig 1 The Company is a Leader In The Industry

Table :2 The Organization Provide Appropriate Training Facilities To Employees

\begin{tabular}{|l|l|l|}
\hline FACTORS & N0 OF RESPONDENTS & PERCENTAGE \\
\hline Strongly agree & 20 & 20 \\
\hline Agree & 44 & 44 \\
\hline Neutral & 4 & 4 \\
\hline Disagree & 28 & 28 \\
\hline Strongly disagree & 4 & 4 \\
\hline TOTAL & 100 & 100 \\
\hline
\end{tabular}

\section{APPROPRIATE TRAINING FACILITIES}

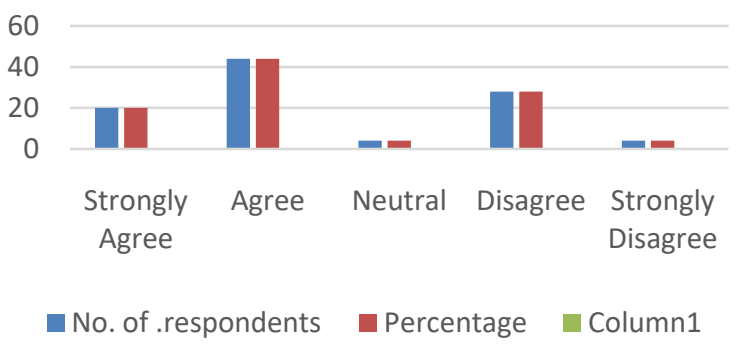

Fig :2 The Organization Provide Appropriate Training Facilities To Employees

TABLE-3 Job Satisfaction

\begin{tabular}{|l|l|l|}
\hline Factors & No of respondents & Percentage \\
\hline Yes & 60 & 60 \\
\hline No & 40 & 40 \\
\hline TOTAL & 100 & 100 \\
\hline
\end{tabular}

TABLE -4. EMPLOYEES TO PARTICIPATE IN DECISION MAKING

\begin{tabular}{|l|l|l|}
\hline Factors & No, of respondents & Percentage \\
\hline Yes & 60 & 60 \\
\hline No & 40 & 40 \\
\hline TOTAL & 100 & 100 \\
\hline
\end{tabular}

nortisingtion in

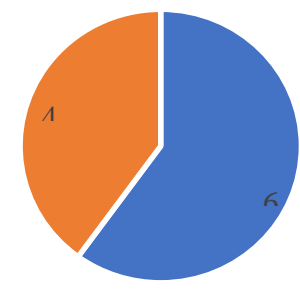

Fig -4. Employees To Participate In Decision Making 
Table-5 Team Spirit In Your Work Environment

\begin{tabular}{|l|l|l|}
\hline Factors & No of respondents & Percentage \\
\hline Strongly satisfied & 12 & 12 \\
\hline Satisfied & 62 & 62 \\
\hline Neutral & 4 & 4 \\
\hline Dissatisfied & 4 & 4 \\
\hline Strongly Dissatisfied & 18 & 18 \\
\hline TOTAL & 100 & 100 \\
\hline
\end{tabular}

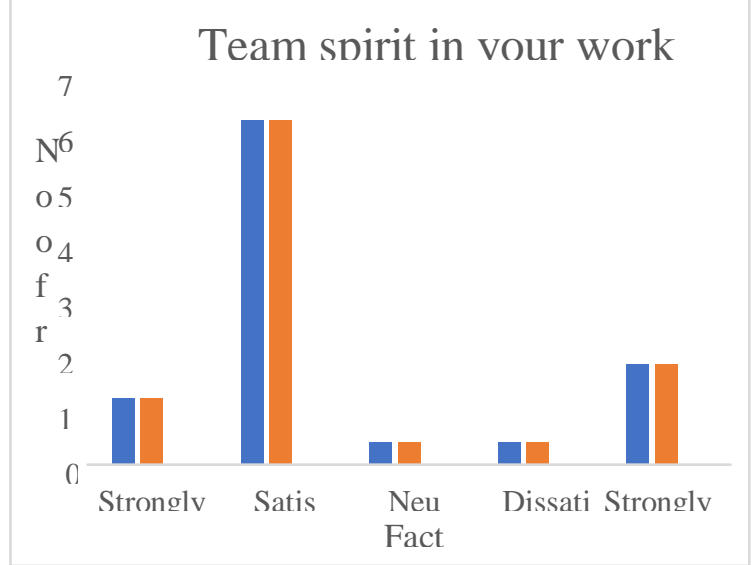

Fig-5 Team Spirit In Your Work Environment

Table-6 Receive Appropriate Recognition For Your

\section{Contribution}

\begin{tabular}{|l|l|l|}
\hline Factors & No. of respondents & Percentage \\
\hline Yes & 80 & 80 \\
\hline No & 20 & 20 \\
\hline Total & 100 & 100 \\
\hline
\end{tabular}

Receive appropriate recognition for

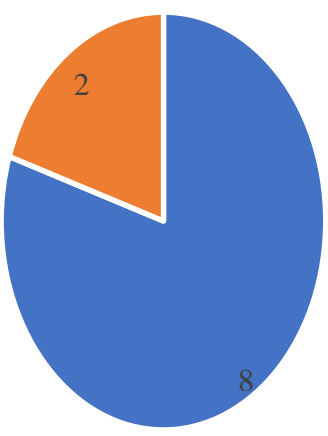

Fig-6 Receive Appropriate Recognition For Your Contribution
Table: 7 Wpm Satisfies Your Social And Economic Needs

\begin{tabular}{|l|l|l|}
\hline Factors & No of Respondents & Percentage \\
\hline Strongly Agree & 20 & 20 \\
\hline Agree & 44 & 44 \\
\hline Neutral & 4 & 4 \\
\hline Disagree & 28 & 28 \\
\hline Strongly Disagree & 4 & 4 \\
\hline TOTAL & 100 & 100 \\
\hline
\end{tabular}

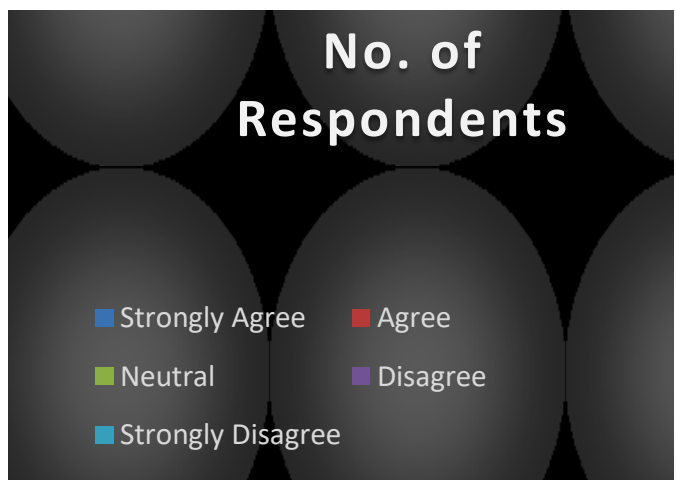

Fig: 7 Wpm Satisfies Your Social And Economic Needs

Table-8 Suggestions Made By Workers Implemented In Tim

\begin{tabular}{|l|l|l|}
\hline Factors & No. of. Respondents & Percentage \\
\hline Strongly Agree & 30 & 30 \\
\hline Agree & 66 & 66 \\
\hline Neutral & 0 & 0 \\
\hline Disagree & 0 & 0 \\
\hline Strongly Disagree & 4 & 4 \\
\hline TOTAL & 100 & 100 \\
\hline
\end{tabular}

\section{No. of. Respondents}

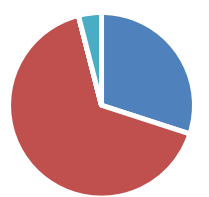

$$
\begin{aligned}
& \text { - Strongly Agree } \quad \text { agree } \\
& \text { - Neutral } \quad \text { Disagree } \\
& \text { - Strongly Disagree }
\end{aligned}
$$


Fig-8 Suggestions Made By Workers Implemented In

Tim

\section{CHI-SQUARE TEST:}

Chi-square is the sum of the squared difference between observed(o) and the expected (e) data (or the deviation,d), divided by the expected data in all possible catagories

\section{Table:9}

\begin{tabular}{|l|l|l|l|l|}
\hline $\mathbf{0}$ & $\mathrm{E}=\mathrm{RT} \mathbf{*}^{*} \mathrm{CT}$ & $(0-\mathrm{E})$ & $(0-\mathrm{E})^{2}$ & $(0-\mathrm{E})^{2} / \mathrm{E}$ \\
& $\mathrm{GT}$ & & & \\
\hline 23 & 25.32 & -2.32 & 5.38 & 0.2124 \\
\hline 26 & 23.68 & 2.32 & 5.38 & 0.2272 \\
\hline 39 & 36.68 & 2.32 & 5.38 & 0.1467 \\
\hline 32 & 34.32 & -2.32 & 5.38 & 0.1568 \\
\hline & & & TOTAL & 0.7431 \\
\hline
\end{tabular}

$$
\chi_{c}^{2}=\sum \frac{\left(O_{i}-E_{i}\right)^{2}}{E_{i}}
$$

Table:10

\begin{tabular}{|l|l|l|l|l|}
\hline 0 & E=RT & $(0-\mathrm{C})$ & $(0-\mathrm{E})^{2}$ & $(0-\mathrm{E})^{2} / \mathrm{E}$ \\
& GT & & & \\
\hline 21 & 35 & -14 & 196 & 5.6 \\
\hline 49 & 35 & 14 & 196 & 5.6 \\
\hline 39 & 25 & 14 & 196 & 7.84 \\
\hline 11 & 25 & -14 & 196 & 7.84 \\
\hline & & & TOTAL & 26.88 \\
\hline
\end{tabular}

$$
\chi_{c}^{2}=\sum \frac{\left(0_{i}-E_{i}\right)^{2}}{E_{i}}
$$

\section{V.RESULTS}

- Majority of the workers were38\% happy with their employments.

- Majorityof the workers were $74 \%$ welcomed the progressions with energetic.
- Majority of the workers felt that organization deals with representative's close to home objectives and help them in arranging their vocations.

- Majority of the respondents are happy with WPM.

- About $41 \%$ of the respondents were moderately aged 25-40 years old. [19],[21],[23]

- The $36 \%$ of the respondents were from business, while $29 \%$ were from government division worker.

- The most extreme number of respondents $32 \%$ had $10000-15000$ and $19 \%$ had $2000-5000$

- A dominant part of 11 respondents are experienced over 10 years. [31],[33],[32]

- Majority of the representatives were $18 \%$ happy with physical offices given by the association.

- Most of the representatives acknowledged that administration thinking about worker assessments, proposals and thoughts for arranging.

- Majority of the $18 \%$ individuals felt that groups are touching off the spirits to perform well.

- Majority of the workers $20 \%$ satisfied with preparing projects gave from by the administration.

- Majority of the workers almost $28 \%$ are unequivocally differ that wpm fulfill social and monetary needs.

- A larger part of 60 respondents are happy with occupation fulfilment

- A $6 \%$ of the respondents Strongly differ the WPM in the executives

- A $28 \%$ of the respondents Strongly fulfills the general specialists support fulfillment level.

\section{DISCUSSION}

The following suggestion evolved from the study:

The executives ought to urge the labourers to take an interest in different gatherings particularly proposal council, and to give many money grants to their great recommendation. [20],[ 22], [24]

- Instead of the money related prizes the administration could give some non-financial prizes to the laborers, for example, acknowledgment, move, and advancement. [25],[27],[29] 
- Management needs to encourage some additionally preparing projects

- The association is proposed to lead an occupation fulfilment review at any rate once per year, to assess and quantify work fulfilment.

\section{CONCLUSION}

The scientist will in general infer that labourers support in the board is a way to diminish control imbalances among the executives and workers. Representative interest in basic leadership procedure improves worker's work responsibility, resolve, upward correspondence and diminish work clashes. So WPM would help to synergize the authoritative targets and individual destinations in an association. The WPM in this association would improve a great deal if the administration gives more consideration, which will guarantee sincere and conductive mechanical relations. [26],[28],[30]

\section{REFERENCES}

1. G BharthVajan R., Ramachandran S.,Psychographic dimensions of training,2016,International Journal of Pharmacy and Technology,V-8,I-4,P-23727-23729

2. Balakrishnan P., Bharthvajan R.,A study on human resource planning in hospitals in Chennai City,2014,International Journal of Applied Engineering Research,V-9,I-22,P-7503-7507

3. Priyadarsini P., Bharthvajan R.,Role of emotional intelligence training programme in reducing the stress of the nurses,2014,International Journal of Applied Engineering Research,V-9,I-22,P-7411-7421

4. Kerinab Beenu G., Bharthvajan R.,Empirical analysis on the cosmetic buying behavior of young women in South India,2014,International Journal of Applied Engineering Research,V-9,I-22,P-7361-7366

5. Balakrishnan P., Bharthvajan R.,Whistling in the wind,2014,International Journal of Applied Engineering Research,V-9,I-22,P-7586-7593

6. Krishnan B., Peter M.,Health hazards of Indian Bpo employee-an alarming issue,2014,International Journal of Applied Engineering Research,V-9,I-22,P-7336-7341

7. Kerinab Beenu G.H., Peter M.,Role of insurance in economic development,2014,International Journal of Applied Engineering Research,V-9,I-22,P-7532-7539

8. Balakrishnan P., Peter M., Priyadarsini P.,Efficiency of safety measures for wellbeing of employees in manufacturing industry,2014,International Journal of Applied Engineering Research,V-9,I-22,P-7376-7382

9. Anbarasi M., Praveen Kumar S.,Online sales promotions of herbal products and its effectiveness towards tanisha.com,2019,Indian Journal of Public Health Research and Development,V-10,I-1,P-195-200

10. Anbarasi M., Praveen Kumar S., Various online marketing and promotions strategies to improve the validation towards the organic products in the pharmaceutical sectors,2019,Indian Journal of Public Health Research and Development,V-10,I-1,P-263-269

11. Loganathan R., Praveen Kumar S.,Grievance handling a key factor for solving issues of employees in an organization,2014,International Journal of Applied Engineering Research,V-9,I-22,P-7483-7491

12. Loganathan R., Praveen Kumar S.,Study on preference of private label brands in super and Hypermarkets,2014,International Journal of Applied Engineering Research,V-9,I-22,P-7327-7335

13. Smitha M., Praveen Kumar S.,Understanding stress and its managementamong the nurses in Chennai city,2014,International Journal of Applied Engineering Research,V-9,I-22,P-7560-7565

14. Kerinab Beenu G.H., Praveen Kumar S.,A study on the investment behavior of Chennai investors in mutual fund schemes,2014,International Journal of Applied Engineering Research,V-9,I-22,P-7520-7525

15. Loganathan R., Praveen Kumar S.,Retention strategies key for organizational productivity,2014,International Journal of Applied Engineering Research,V-9,I-22,P-7443-7447

16. Pavithra J., Ganesan M., Brindha G.,State wise analysis of microfinance sector in India,2016,International Journal of Pharmacy and Technology,V-8,I-4,P-23417-23432
17. Pavithra J., Ganesan M.,A comparative study on microfinance in India and abroad,2016,International Journal of Applied Business and Economic Research,V-14,I-8,P-5471-5476

18. Pavithra J., Ganesan M.,A study on awareness and impact of micro-financial schemes,2016,International Journal of Applied Business and Economic Research,V-14,I-8,P-5449-5460

19. Senthilmurugan P., Pavithra J.,Consumer preference towards organised retailing with reference to Big Bazaar,2014,International Journal of Applied Engineering Research,V-9,I-22,P-7469-7475

20. Senthilmurugan P., Pavithra J.,Implication of social media marketing in growing healthcare industry,2014,International Journal of Applied Engineering Research,V-9,I-22,P-7448-7456

21. Loganathan R., Pavithra J.,Consumer perception towards private label brand over other brands in super markets and hypermarkets,2014,International Journal of Applied Engineering Research,V-9,I-22,P-7355-7360

22. Kerinab Beenu G., Pavithra J.,Tradeâ€"off between liquidity and profitability in logistics industry,2014,International Journal of Applied Engineering Research,V-9,I-22,P-7398-7401

23. Kerinab Beenu G., Pavithra J.,A study on the prospective consumerâ $€^{\mathrm{TM}_{\mathrm{S}}}$ perception towards utility cars in Chennai city,2014,International Journal of Applied Engineering Research,V-9,I-22,P-7526-7531

24. Pavithra J., Dilli Babu P., Ambuli T.V.,A study on budgetary control at Maruti Service Masters, Chennai,2014,International Journal of Applied Business and Economic Research,V-12,I-2,P-151-161

25. Pavithra J., Dilli Babu P., Ambuli T.V.,A study on customer satisfaction of retro Garments Pvt Ltd, Chennai,2014,International Journal of Applied Business and Economic Research,V-12,I-2,P-381-391

26. Kerinab Beenu G.H., Pavithra J., Senthilmurugan P.,A study on the influence of promotional activities for TATA ARIA among consumers in Chennai,2014,International Journal of Applied Engineering Research,V-9,I-22,P-7572-7578

27. Vijayaragavan S.P.,An investigative expert that's general FBG sensors,International Journal of Mechanical Engineering and Technology,V-8,I-8,PP-1500-1505,Y-2017

28. Vijayaragavan S.P.,Equalization routing protocol for Wi-Fi sensor strategy,International Journal of Mechanical Engineering and Technology,V-8,I-8,PP-1662-1666,Y-2017

29. Karthik B., Kiran Kumar T.V.U., Vijayaragavan P., Bharath Kumaran E.,Design of a digital PLL using 0.35 $\hat{\mathrm{I}}^{1 / 4} \mathrm{~m}$ CMOS technology,Middle East Journal of Scientific Research,V-18,I-12,PP-1803-1806,Y-2013

30. Kanniga E., Selvaramarathnam K., Sundararajan M.,Kandigital bike operating system,Middle - East Journal of Scientific Research,V

31. Jasmin M., Vigneshwaran T., Beulah Hemalatha S.,Design of power aware on chip embedded memory based FSM encoding in FPGA,International Journal of Applied Engineering Research,V-10,I-2,PP-4487-4496,Y-2015

32. Jasmin M.,Optimization techniques for low power VLSI circuits,Middle East Journal of Scientific Research,V-20,I-9,PP-1082-1087,Y-2014

33. Jasmin M., Vigneswaran T.,Fuzzy controller for error control of on - Chip communication,2017 International Conference on Algorithms, Methodology, Models and Applications in Emerging Technologies, ICAMMAET 2017,V-2017-January,I-,PP-1-5,Y-2017

\section{AUTHORS PROFILE}

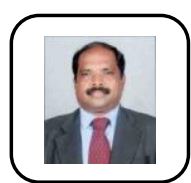

Ramamoorthy $\mathbf{R}$ Assistant Professor ,Department of MBA, Bharath Institute of Higher Education and Research, Tamilnadu, India

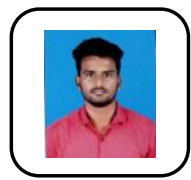

Karthikeyan P Student ,Department of MBA, Bharath Institute of Higher Education and Research, Tamilnadu, India

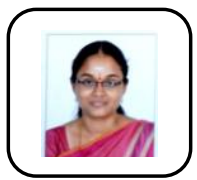

Shanmughapriya K Assistant Professor ,Departmen of CSE, Bharath Institute of Higher Education and Research, Tamilnadu, India 